\title{
RESEARCH OF THE MATHEMATICAL MODEL FOR CONTINUOUS PSEUDO-EDUCATION OF ROBOTS
}

\author{
N. V. Oshchepkova, Perm State University, Perm, Russian Federation, nvo@psu.ru.
}

\begin{abstract}
We consider mathematical models describing the pseudo-education of robots and the emotions of robots arising as a result of continuous impact. The article investigates the hypothesis of possibility to decompose the total pseudo-education of robots into a sum of positive and negative components. We formulate and prove the theorem on the necessary and sufficient conditions to decompose the total positive pseudo-education of an unforgiving robot into the sum of positive pseudo-education and negative pseudo-education. We show that the considered hypothesis is not true for evenly-forgetful robots. The article describes ways to determine unforgiving and not unforgiving robots.

Keywords: robot, education, emotions, mathematical modeling.
\end{abstract}

\section{Introduction}

The papers $[1,2,3,4]$ describe the mathematical models to calculate the pseudoeducation of a robot, formed by both continuous impact on the robot by events and emotions of the robot arising as a result of the impact:

$$
R_{i}=r_{i}+\Theta_{i} \cdot R_{i-1}
$$

where $i$ is a number of the event that impacts on the robot and generates an elementary pseudo-education $r_{i}$ of the robot, $R_{i}$ is the total pseudo-education of the robot obtained as a result of the impact on the robot of $i$-th event, $\Theta_{i}$ is a memory coefficient characterizing the fraction of the previous total pseudo-education that the robot remembers at the time when the $i$-th event impacts on the robot, $\Theta_{i} \in[0 ; 1)$.

Let us formulate the hypotheses that the pseudo-education of a robot can be represented in the form $R_{i}=R_{i}^{+}+R_{i}^{-}$, i.e. any pseudo-education is a sum of positive part $R_{i}^{+}$and negative part $R_{i}^{-}$, where $R_{i}^{+}>0, R_{i}^{-}<0$, and $R_{i}^{+}$and $R_{i}^{-}$satisfy the following formulas

$$
R_{i}^{+}=r_{i}^{+}+\Theta^{+} \cdot R_{i-1}^{+}, \quad R_{i}^{-}=r_{i}^{-}+\Theta^{-} \cdot R_{i-1}^{-},
$$

where $r_{i}^{+}>0$ is a positive perception, $r_{i}^{-}<0$ is a negative perception, $\Theta^{+} \in[0 ; 1)$ is a memory coefficient of the positive perception, $\Theta^{-} \in[0 ; 1)$ is a memory coefficient of the negative perception.

According to the paper [3], a robot is called unforgiving, if the condition $\Theta^{-}>\Theta^{+}$ holds, and a robot is called not unforgiving, if $\Theta^{-}<\Theta^{+}$.

\section{Model Description}

Let us describe the model to determine whether a robot is unforgiving or not. It is easy to see that the condition $r_{i}^{+}>0$ implies $R_{i}^{+}>0$, and the condition $r_{i}^{-}<0$ implies $R_{i}^{-}<0$, where $i=\overline{1, n}$. 
Let $r_{i}^{+}=q^{+}=$const, $r_{i}^{-}=q^{-}=$const. In this case

$$
R_{i}^{+}=q^{+} \cdot \frac{1-\left(\Theta^{+}\right)^{i}}{1-\Theta^{+}}, \quad R_{i}^{-}=q^{-} \cdot \frac{1-\left(\Theta^{-}\right)^{i}}{1-\Theta^{-}}
$$

and $R_{i}$ can be represented in the form

$$
R_{i}=q^{+} \cdot \frac{1-\left(\Theta^{+}\right)^{i}}{1-\Theta^{+}}+q^{-} \cdot \frac{1-\left(\Theta^{-}\right)^{i}}{1-\Theta^{-}}
$$

Let us give the definitions. A positive perception part of pseudo-education of the robot is a parameter $\Theta^{+}$satisfying the following formula:

$$
\frac{1-\left(\Theta^{+}\right)^{i}}{1-\Theta^{+}}
$$

and a negative perception part of pseudo-education of the robot is a parameter $\Theta^{+}$ satisfying the following formula:

$$
\frac{1-\left(\Theta^{-}\right)^{i}}{1-\Theta^{-}}
$$

where $q^{+}>0, \Theta^{+} \in[0 ; 1), q^{-}<0, \Theta^{-} \in[0 ; 1)$.

\section{Research of the Model}

Consider the following case. The total perception is positive, but the robot still pays attention to negative perception.

Prove the theorem that connects the parameters $q^{+}, q^{-}$, when $\Theta^{-}>\Theta^{+}$and the inequality $R_{i}>0$ holds.

Theorem 1. Let the total pseudo-education be greater than zero. Then the modulus of negative pseudo-education part is less than the modulus of positive pseudo-education part if and only if the following inequality holds:

$$
\frac{q^{+}}{1-\Theta^{+}}>-\frac{q^{-}}{1-\Theta^{-}}
$$

Proof.

Necessity. Consider a robot with the general positive pseudo-education, i.e. $R_{i}>0$, then the formula (4) implies that

$$
q^{+} \cdot \frac{1-\left(\Theta^{+}\right)^{i}}{1-\Theta^{+}}+q^{-} \cdot \frac{1-\left(\Theta^{-}\right)^{i}}{1-\Theta^{-}}>0 .
$$

For $i \rightarrow \infty$, taking into account that $\Theta^{+} \in[0 ; 1)$ and $\Theta^{-} \in[0 ; 1)$, we have the inequality

$$
\frac{q^{+}}{1-\Theta^{+}}>-\frac{q^{-}}{1-\Theta^{-}}
$$

Therefore, if the total pseudo-education of a robot is greater than zero, then the modulus of the negative pseudo-education part is less than the modulus of the positive pseudo-education part. 
Sufficiency. Consider decomposition of the pseudo-education of a robot, described by the formula (4), which implies that the parameter $q^{+}$is the following:

$$
q^{+}=\left(R_{i}-q^{-} \cdot \frac{1-\left(\Theta^{-}\right)^{i}}{1-\Theta^{-}}\right) \cdot \frac{1-\Theta^{+}}{1-\left(\Theta^{+}\right)^{i}}
$$

Note that the following inequality holds: $\frac{q^{+}}{1-\Theta^{+}}>-\frac{q^{-}}{1-\Theta^{-}}$. Then, taking into account that $1-\Theta^{+}>0$, we have $q^{+}>-q^{-} \cdot \frac{1-\Theta^{+}}{1-\Theta^{-}}$.

Therefore,

$$
\left(R_{i}-q^{-} \cdot \frac{1-\left(\Theta^{-}\right)^{i}}{1-\Theta^{-}}\right) \cdot \frac{1-\Theta^{+}}{1-\left(\Theta^{+}\right)^{i}}>-q^{-} \cdot \frac{1-\Theta^{+}}{1-\Theta^{-}}
$$

This inequality implies that $R_{i}$ can be represented as $R_{i}>q^{-} \cdot \frac{\left(\Theta^{+}\right)^{i}-\left(\Theta^{-}\right)^{i}}{1-\Theta^{-}}$, then for $i \rightarrow \infty$ the numerator of the fraction tends to zero, because $\Theta^{+} \in[0 ; 1)$ and $\Theta^{-} \in[0 ; 1)$, i.e. $R_{i}>0$. This completes the proof.

Consider evenly-forgetful robots [1], i.e. $R_{i}=q \cdot \frac{1-\Theta^{i}}{1-\Theta}$.

It is easy to see that within the framework of the hypothesis for several pseudoeducational events, starting with the first one, the following equations are true:

$$
q \cdot \frac{1-\Theta^{i}}{1-\Theta}=q^{+} \cdot \frac{1-\left(\Theta^{+}\right)^{i}}{1-\Theta^{+}}+R_{i}^{-}+q^{-} \cdot \frac{1-\left(\Theta^{-}\right)^{i}}{1-\Theta^{-}}, \quad i=\overline{1, n} .
$$

Unknown parameters in the system are $q, \Theta, q^{+}, \Theta^{+}, q^{-}, \Theta^{-}$. For $n=6$ the system takes the form:

$$
\left\{\begin{array}{l}
q=q^{+}+q^{-}, \\
q \cdot \frac{1-\Theta^{2}}{1-\Theta}=q^{+} \cdot \frac{1-\left(\Theta^{+}\right)^{2}}{1-\Theta^{+}}+q^{-} \cdot \frac{1-\left(\Theta^{-}\right)^{2}}{1-\Theta^{-}} \\
q \cdot \frac{1-\Theta^{3}}{1-\Theta}=q^{+} \cdot \frac{1-\left(\Theta^{+}\right)^{3}}{1-\Theta^{+}}+q^{-} \cdot \frac{1-\left(\Theta^{-}\right)^{3}}{1-\Theta^{-}} \\
q \cdot \frac{1-\Theta^{4}}{1-\Theta^{5}}=q^{+} \cdot \frac{1-\left(\Theta^{+}\right)^{4}}{1-\Theta^{+}}+q^{-} \cdot \frac{1-\left(\Theta^{-}\right)^{4}}{1-\Theta^{-}} \\
q \cdot \frac{1-\Theta^{5}}{1-\Theta^{-}}=q^{+} \cdot \frac{1-\left(\Theta^{+}\right)^{5}}{1-\Theta^{+}}+q^{-} \cdot \frac{1-\left(\Theta^{-}\right)^{2}}{1-\Theta^{-}} \\
q \cdot \frac{1-\Theta^{6}}{1-\Theta}=q^{+} \cdot \frac{1-\left(\Theta^{+}\right)^{6}}{1-\Theta^{+}}+q^{-} \cdot \frac{1-\left(\Theta^{-}\right)^{6}}{1-\Theta^{-}}
\end{array}\right.
$$

Let us investigate the solution of this system. Obviously, unknown parameters must satisfy the following conditions:

$$
q>0, \quad q^{+}>0, \quad q^{-}<0, \quad \Theta \in[0 ; 1), \quad \Theta^{+} \in[0 ; 1), \quad \Theta^{-} \in[0 ; 1) .
$$

The solution of the system found by Mathematica [6] does not satisfy the conditions (7). Therefore, the hypothesis for six events is not true. 
Similarly, the solutions of the system for $n=5$

$$
\left\{\begin{array}{l}
q=q^{+}+q^{-}, \\
q \cdot \frac{1-\Theta^{2}}{1-\Theta^{3}}=q^{+} \cdot \frac{1-\left(\Theta^{+}\right)^{2}}{1-\Theta^{+}}+q^{-} \cdot \frac{1-\left(\Theta^{-}\right)^{2}}{1-\Theta^{-}} \\
q \cdot \frac{1-\Theta^{3}}{1-\Theta^{+}}=q^{+} \cdot \frac{1-\left(\Theta^{+}\right)^{3}}{1-\Theta^{+}}+q^{-} \cdot \frac{1-\left(\Theta^{-}\right)^{3}}{1-\Theta^{-}} \\
q \cdot \frac{1-\Theta^{4}}{1-\Theta^{-}}=q^{+} \cdot \frac{1-\left(\Theta^{+}\right)^{4}}{1-\Theta^{+}}+q^{-} \cdot \frac{1-\left(\Theta^{+}\right.}{1-\Theta^{-}} \\
q \cdot \frac{1-\Theta^{5}}{1-\Theta}=q^{+} \cdot \frac{1-\left(\Theta^{+}\right)^{5}}{1-\Theta^{+}}+q^{-} \cdot \frac{1-\left(\Theta^{-}\right)^{5}}{1-\Theta^{-}}
\end{array}\right.
$$

and the coefficients $\Theta$, which take values from the set $\{0,0.05,0.1, \ldots, 0.95\}$, also do not satisfy the conditions (7).

Solutions of the system for $n=4$

$$
\left\{\begin{array}{l}
q=q^{+}+q^{-} \\
q \cdot \frac{1-\Theta^{2}}{1-\Theta^{3}}=q^{+} \cdot \frac{1-\left(\Theta^{+}\right)^{2}}{1-\Theta^{+}}+q^{-} \cdot \frac{1-\left(\Theta^{-}\right)^{2}}{1-\Theta^{-}} \\
q \cdot \frac{1-\Theta^{3}}{1-\Theta}=q^{+} \cdot \frac{1-\left(\Theta^{+}\right)^{3}}{1-\Theta^{+}}+q^{-} \cdot \frac{1-\left(\Theta^{-}\right)^{3}}{1-\Theta^{-}} \\
q \cdot \frac{1-\Theta^{4}}{1-\Theta}=q^{+} \cdot \frac{1-\left(\Theta^{+}\right)^{4}}{1-\Theta^{+}}+q^{-} \cdot \frac{1-\left(\Theta^{-}\right)^{4}}{1-\Theta^{-}}
\end{array}\right.
$$

and the coefficients $\Theta$ and $\Theta^{+}$, which take values from the set $\{0,0.05,0.1, \ldots, 0.95\}$, also do not satisfy the conditions (7).

Also, the solutions of the system for $n=3$

$$
\left\{\begin{array}{l}
q=q^{+}+q^{-} \\
q \cdot \frac{1-\Theta^{2}}{1-\Theta}=q^{+} \cdot \frac{1-\left(\Theta^{+}\right)^{2}}{1-\Theta^{+}}+q^{-} \cdot \frac{1-\left(\Theta^{-}\right)^{2}}{1-\Theta^{-}} \\
q \cdot \frac{1-\Theta^{3}}{1-\Theta}=q^{+} \cdot \frac{1-\left(\Theta^{+}\right)^{3}}{1-\Theta^{+}}+q^{-} \cdot \frac{1-\left(\Theta^{-}\right)^{3}}{1-\Theta^{-}}
\end{array}\right.
$$

and the coefficients $\Theta, \Theta^{+}$and $\Theta^{-}$, which take values from the set $\{0,0.05,0.1, \ldots, 0.95\}$, do not satisfy the conditions $(7)$.

Therefore, for evenly-forgetting robots, the hypothesis of the decomposition of pseudoeducation into a sum of the positive perception part and the negative perception part is not true.

However, for unevenly-forgetting robots, the hypothesis may be true. Consider examples of such robots.

Let the robot be not unforgiving with characteristics given in Table 1.

Table 1

Values of not unforgiving robot parameters

\begin{tabular}{|l|l|l|l|l|}
\hline Parameters & $q^{+}$ & $\Theta^{+}$ & $q^{-}$ & $\Theta^{-}$ \\
\hline Values & 65 & 0,6 & -45 & 0,4 \\
\hline
\end{tabular}


The total pseudo-education $R_{i}$ for values from the Table 1 is given in Fig. 1 .

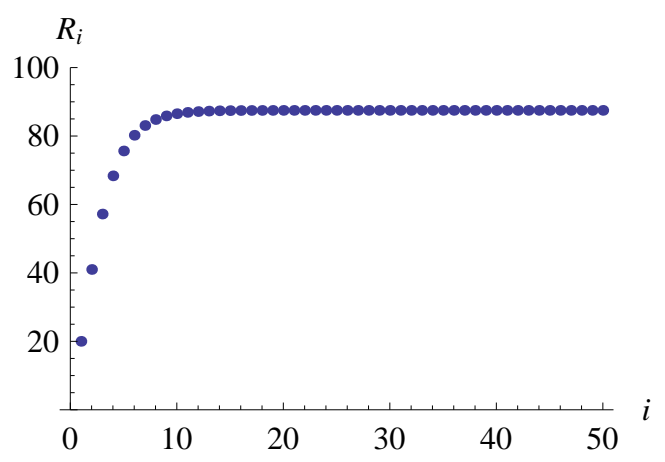

Fig. 1. Graph of pseudo-education of not unforgiving robot

Table 2 gives characteristics of the unforgiving robot.

Table 2

Values of the unforgiving robot parameters

\begin{tabular}{|l|l|l|l|l|}
\hline Parameters & $q^{+}$ & $\Theta^{+}$ & $q^{-}$ & $\Theta^{-}$ \\
\hline Values & 80 & 0,4 & -25 & 0,8 \\
\hline
\end{tabular}

The total pseudo-education $R_{i}$ for values from the Table 2 is given in Fig. 2 .

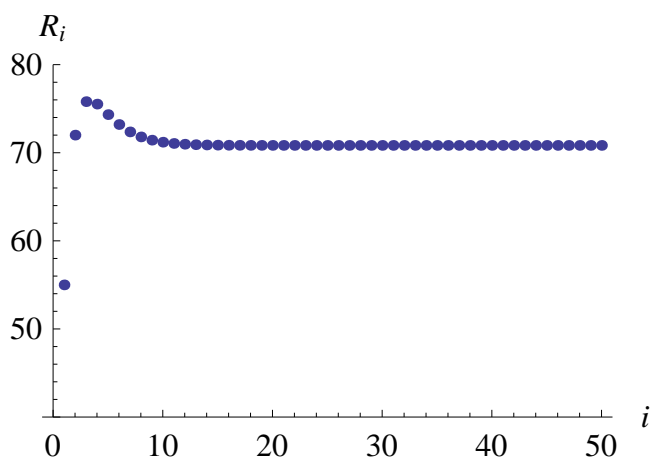

Fig. 2. Graph of pseudo-education of the unforgiving robot

\section{Conclusion}

The paper shows that the hypothesis of the decomposition of pseudo-education into positive and negative components is not true for evenly-forgetful robots, but for not evenlyforgetful robots this hypothesis is true.

Also, for not evenly-forgetful robots we can determine whether a robot is unforgiving or not, when the total pseudo-education is positive. 


\section{References}

1. Pensky O.G., Chernikov K.V. Fundamentals of Mathematical Theory of Emotional Robots. Perm, Perm State University, 2010.

2. Chernikov K.V. Matematicheskie modeli robotov s neabsoliutnoi pamiatiu. [Mathematical Models of Robots with a Non-Absolute Memory. The Dissertation for Scientific Degree of the Candidate of Physico-Mathematical Sciences]. Perm, Perm State University, 2013. (in Russian)

3. Shafer A.E. Ambivalent Robot Mathematical Emotions Models. Bulletin of Perm University. Mathematics. Mechanics. Computer Science, 2015, issue 2(29), pp. 63-67. (in Russian)

4. Shafer A.E., Penskiy O.G. Mathematical Models Vindictive and Not Vindictive Robots. Fundamental research, 2016, no. 10-2, pp. 360-363. (in Russian)

5. ELSYS, available at: http://www.elsys.ru/ (accessed on 12 December 2015). (in Russian)

6. MATHEMATICA Package, available at: http://www.exponenta.ru/educat/systemat/ lerner/1.asp (accessed on 1 March 2016). (in Russian)

Natalia V. Oshchepkova, Department of Higher Mathematics, Perm State University (Perm, Russian Federation), nvo@psu.ru.

\section{ИССЛЕДОВАНИЕ МАТЕМАТИЧЕСКОЙ МОДЕЛИ НЕПРЕРЫВНОГО ПСЕВДОВОСПИТАНИЯ РОБОТОВ}

\section{Н.В. Ощепкова}

В статье рассматриваются математические модели, описывающие псевдооспитание роботов и эмоции, возникающие у них в результате непрерывного воздействия. В статье проведены исследования гипотезы о возможности разложения общего псевдовоспитания роботов на сумму положительной и отрицательной компоненты. Сформулирована и доказана теорема о необходимых и достаточных условиях при разложении общего положительного псевдовоспитания злопамятного робота на сумму положительного псевдовоспитания и отрицательного псевдовоспитания. Автором показано, что рассматриваемая гипотеза не верна для равномернозабывчивых роботов.

Ключевые слова: робот, воспитание, эмочии, математическое моделирование. 


\section{Литература}

1. Пенский, О.Г. Основы математической теории эмоциональных роботов / О.Г. Пенский, К.В. Черников. - Пермь: Перм. гос. ун-т., 2010.

2. Черников, K.В. Математические модели роботов с неабсолютной памятью: дис. ... канд. физ.-мат. наук / K.В. Черников. - Пермь: Перм. нац. исслед. политехн. ун-т, 2013.

3. Шафер, А.Е. Модель амбивалентных эмоций робота / А.Е. Шафер // Вестник Пермского университета. Математика. Механика. Информатика. - 2015. Вып. 2(29). - C. 63-67.

4. Шафер, А.Е. Математические модели злопамятных и незлопамятных роботов / А.Е. Шафер, О.Г. Пенский // Фундаментальные исследования. - 2016. - № 10-2. - C. 360-363.

5. ЭЛСИС [Электронный ресурс]. URL: http://www.elsys.ru/ (дата обращения: 12.12.2015).

6. Пакет Математика [Электронный pecypc]. URL: http://www.exponenta.ru/educat/systemat/lerner/1.asp (дата обращения: 01.03.2016).

Ощепкова Наталья Владимировна, кафедра высшей математики, Пермский государственный начиональный исследовательский университет (ә. Пермь, Российская Федерачия),nvo@psu.ru.

Поступила в редакцию 6 ноября 2017 г. 